\title{
SOUTH AFRICA AND THE WAR IN ASIA MINOR 1920-1923'
}

\author{
Major I.J. van der Waag \\ Documentation Service, SADF
}

\begin{abstract}
The need for a South African expeditionary force was again experienced only two years after the end of the First World War. The border conflicts and minor wars which followed the treaties signed in Paris in 1919 and 1920, emphasized the fact that South Africa required infantry, artillery and engineer units which could be mobilized into an effective task force. The war in Asia Minor (1920-1923), in particular, revealed severe inadequacies in both the organization of the Union Defence Force and the defence policy of the Empire.
\end{abstract}

Paradoxically the War in Asia Minor can be said to have had its start at the Paris Peace Conference, which was convened ten weeks after the close of the First World War to settle the new world order. After long deliberation, the peace settlements with the ex-enemy countries were finally embodied in five treaties:

(1) Versailles (28 June 1919) - treaty with Germany.

(2) St Germain (10 September 1919) - treaty with Austria.

(3) Neuilly (27 November 1919) - treaty with Bulgaria.

(4) Trianon (4 June 1920) - treaty with Hungary.

(5) Sèvres (10 August 1920) - treaty with Turkey.

However, the international settlement was generally frustrated by the chief players - Clemenceau, Lloyd George, Orlando and Wilson - who were more concerned with exacting vengeance and making rewards, than finding a solution which would lead to a lasting peace in Europe.

The Conference rewarded "friendly" peoples with recognition of their right to self-determination, and cold-shouldered the rights of those who had supported or sympathized with the Central Powers during the war. The Treaty of
Sèvres almost caused a world war in 1922; and, to a large extent, the other four treaties were a major cause of the world war which erupted in $1939^{2}$ and the Yugoslavian civil war which has been raging since 1991 .

\section{TREATY OF SÈVRES (1920)}

The terms of the treaty with Turkey, thrashed out between the Allies at Sèvres, were announced in May 1920 and signed on 10 August. In effect, it carved the remnant of the Ottoman Empire into various fragments shared out between Greece, Britain, France, Italy and friendly Arabs, so virtually destroying the independence of Turkey. She lost Arabia, Palestine, Syria and Mesopotamia; and renounced all rights in Africa and the Mediterranean islands. Armenia was to be independent; and autonomy was to be granted to Kurdistan. In Europe, Eastern Thrace was assigned to Greece, and provisionally Greece was also awarded Smyrna and a zone around it (map 1). ${ }^{3}$ A tripartite agreement between Britain, France and Italy laid out French and Itàlian spheres of influence in those parts of Turkey which, under the peace treaty, were nominally left to the Turks; while the Straits and Constantinople were internationalized and came under the control of the League of Nations. ${ }^{4}$

Unless otherwise stated, all of the archival material referred to in the references that follow, are held in the custody of the Documentation Service, SADF.

P.H Bell: The Origins of the Second World War in Europe (London and New York 1988).

Greece, a late entrant to the war, claimed the Smyrna area as part of her war gains at he Paris Peace Conference. This was resisted by the Americans and was bitterly opposed by the Italians who claimed that Smyrna had been earmarked for them by the secret treaties of London (1915) and St Jean de Maurienne (1917). Greece, however, received the support of Britain and France; and the Italian delegation withdrew from the talks. To settle the matter, both the Greeks and the Italians sought to present the Conference with a Fait accompli. A Greek force was landed at Smyrna on 14May 1919, and occupied the town and hinterland. (G.M. Gathorne-Hardy: A Short History of International Affairs, 1920-1939 (London. New York and Toronto, 1950), pp. 117-118.)

4 British Parliamentary Papers (hereafter BPP), Cmd.963-1920 Tripartite Agreement between the British Empire, France and Italy respecting Anatolia signed at Sèvres August 10, 1920. 


\section{DISPUTE AMONG THE ALLIES}

However, before the treaty had even been signed, the Allies began to work in opposition to each other. Italy, seeking commercial advantage and the resurrection of the Roman Empire (map 2), made political capital to the detriment of the other Allies and particularly the Greeks, who had snatched Smyrna from her. Britain, in turn, encouraged the Greeks to make war on the Turks and so not only stretch the boundaries of Greece into Asia Minor, but also buffer Italian imperialism. The Greek government of prime minister Venizelos envisioned the recreation of the ancient Greek empire in Turkey (map 1), a land in which there were still large numbers of Greek-speaking people. Britain loaned Greece large sums of money and supplied munitions for the great offensive. This policy was in opposition to the interests of France and Italy, and naturally they in turn, to maintain the balance of power, aligned themselves with Turkey and supplied the Turkish nationalists with the munitions necessary to drive the Greeks back. ${ }^{5}$

Although British policy remained largely unaltered, she too had a commercial interest. Constantinople lay on the direct sea route to Batum, a town connected by rail to Baku, the centre of the Caspian oilfields. After a great deal of trouble and expense and some fighting during the First World War, Britain had secured a mandate over the Mesopotamian (Iraqi) oilfields. However, these were hardly sufficient for the British Empire and, in the mechanically-propelled age, Batum was expected to become a port of great importance. Plunkett Woodgate, a member of the British Intelligence Staff at Constantinople, showed great foresight when in 1922, he stated : "To-day a man's value is estimated in pounds sterling, to-morrow it may be in litres of oil! ${ }^{6}$

Imperial and naval strategy were the grounds for the British government's support of the Greeks. Thus, in 1921, when the Greeks could have extricated from Asia Minor, they did not do so, in part trusting to Lloyd George's support.

\section{THE WAR}

In June 1919, the Turkish nationalists under Mustapha Kemal had begun their agitation to drive all foreigners from Turkey. The terms of the treaty dictated at Sèvres, undoubtedly strengthened their hand; and by the end of that year, the de facto control of the country passed from the Sultan's palace in Constantinople to Kemal's headquarters in Angora (now Ankara). In June 1920, Kemalist forces brought the British and French garrisons under siege. The two Allies, then accepted an offer from Venizelos, the Greek prime minister, to send a Greek force to cope with the situation. The Greek advance began at once, and was at first unexpectedly successful. The Kemalist forces were driven back, the treaty of Sèvres was signed by the Sultan at Constantinople (10 August 1920), and for the moment the outlook seemed promising.

However, the war went on and things began to turn against Greece. Firstly, following the fall of Venizelos and the return to the throne of King Constantine at the end of 1920, the Allies had little enthusiasm for Greece under her old proGerman ruler. She was practically left friendless; the Allies proclaiming their own neutrality and the neutrality of the Straits in May 1921. In March 1921, a new spectre appeared. The Soviet Union and Turkey concluded an alliance, and Kemal received large supplies of Russian munitions. As a result, the Greek offensive started in January 1921, was halted after almost reaching Angora; and the Greek forces were defeated at Sakarya River in September of that year (map 3).

However, France's defection from the "Allied camp" was a third and even more fatal consideration. Whereas the British and Italians had taken up their quarters in Pera, the European quarter of Constantinople; the French troops were billeted in the Turkish quarter of Stamboul. Here the French got a first-hand opportunity to work with the Turks, all of whom spoke French. With Germany defeated, France hoped to draw Turkey into her sphere of influence. She exploited every opportunity and in this was forced to play a double part. She had to keep in close and friendly relations with her Allies, and at the same time carry on a sort of political intrigue with the Turkish nationalist leader, Mustapha Kemal. ${ }^{7}$ Eventaully, on 20 October 1921, France secretly signed a separate armistice with Kemal. From this date, the state of war between France and Angora ceased, and France received mining and other concessions in Cilicia. ${ }^{8}$

Allies in Opposition, Cape Times, 29 Sep 1922; and C.L.Mowat: Britain between the Wars, 1918-1940 (London 1955), p.117.

- Hon. Plunkett Woodgate : At Constantinople; The Political Aspect; Britain's Position, Cape Times, 29 Sep 1922.

Hon. Plunkett Woodgate : At Constantinople; The Political Aspect; The Attitude of France, Cape Times, 28 Sep 1922.

8 BPP, Cmd.1556-1921 Despatch from His Majesty's Ambassador at Paris, enclosing the Franco-Turkish Agreement signed at Angora on October 20, 1921. 


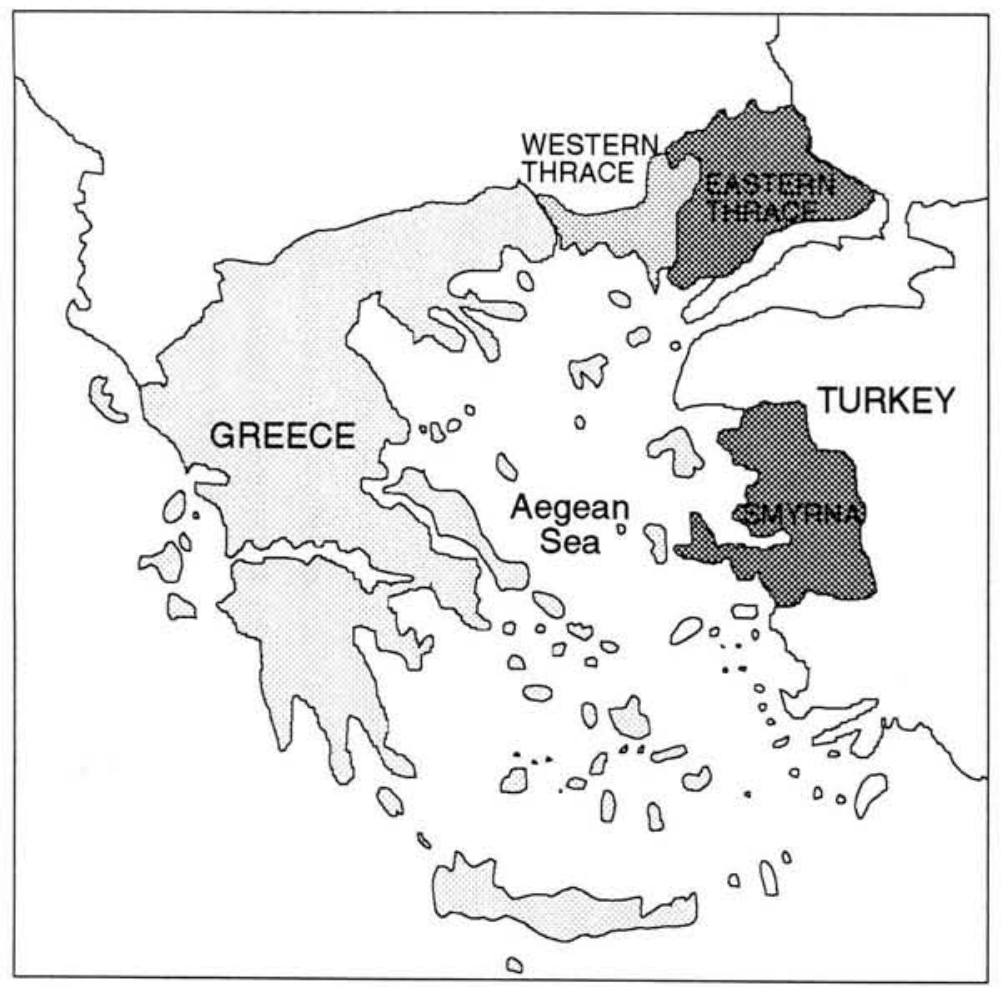

\section{Greece in 1914}

Ceded by Bulgaria; Greek possession confirmed by Treaty of Neuilly 1919.

Ceded by Turkey by Treaty of Sèvres 1920; restored to Turkey by Treaty of Lausanne 1923.

Map 1 : Greek attempts to encircle the Aegean.

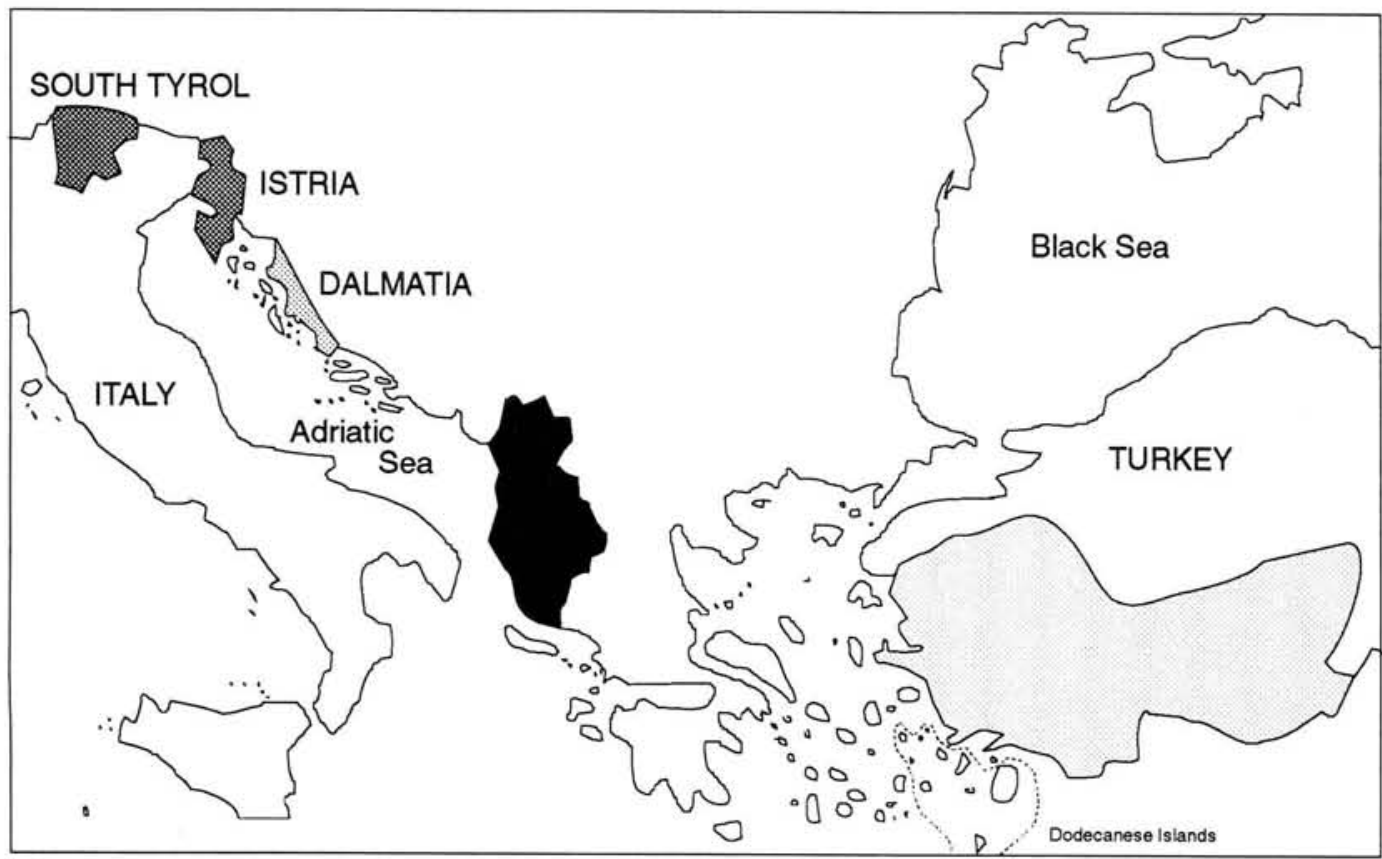

\section{Italy in 1914}

Territory recieved by Italy after WW I

Promised to Italy if Turkey were to be partitioned.

Austro-Hungarian territory promised to Italy but handed over to Yugoslavia.

The Dodecanese islands had been occupied by Italy since 1912. Albania

Map 2 : Italian aspirations at expansion in Europe, 1919-1939. 
However, still trusting Britain for support, Greece rejected the proposals for the modification of the Treaty of Sèvres made at the London Conference in February 1922, and in the summer began a new offensive aimed at Angora.

The Turkish counter-offensive began on $18 \mathrm{Au}$ gust 1922, the Greeks were routed at the battle of Afium Karahissar, and 14 days later (9 September) the Turkish cavalry was in Smyrna, 200 miles to the west. Reports after the battle of Sakarya, stressed the inferior equipment of the Greeks, their poor artillery, the erratic supply of ammunition, the uneconomical employment of their fire power and the absence of the higher control of their artillery. Another of their prime weaknesses appears to have been the lack of cavalry, while the Turks were reported to muster two divisions of over 6000 sabres. From the outcome, it was clear that the Turks had made full use of their cavalry superiority in relentlessly pressing the pursuit.?

\section{BRITISH INTERVENTION}

The rampant Turkish forces, now drunk with victory, produced a dangerous situation. With the Greek army annihilated and no longer able to offer serious resistance to the Turks; they ceased to exist as an instrument for the enforcement of the Treaty of Sèvres. This created a power vacuum and forced the Allies to prepare to uphold their prestige before the world, by taking firm military action should the Turks threaten the neutral zone at the Straits. At first, Britain and France agreed to act in concert by opposing any Turkish violation of these zones. Although differences continued to divide them, there was some hope for a united front. The War Office reported that the Little Entente, Yugoslavia and Rumania, had indicated their intention to support Greece; and as the Little Entente was a protegé of France, the British hoped that such action would again ensure French support of the Allied demands. ${ }^{10}$

All in all, however, the War Office presented a very gloomy picture to the British government. It was apparent that a large measure of Bolshevist support was responsible for the Turkish victories; and, although it appeared impossible for the Turks to cross from the Ismid Peninsula to
Constantinople whilst the Allied fleet guarded the Straits, there remained the possibility of a joint Turko-Soviet attack through Rumania. If, as Moscow declared, the Soviet Union was prepared to support Turkey in her claims, the possibility of a world conflict of the first magnitude, was raised - "a struggle for the existence of the Empire such as that from which we have only recently emerged". ${ }^{11}$ The existence of a treaty between the Soviet government and Angora, and intelligence that Kemal had paused in his military operations in order to consult with Moscow, confirmed suspicions that the Kemalists were embroiled with the Bolshevists. The War Office believed that the Soviet Union hoped to throw the Near East into chaos and so further divide the Allies. ${ }^{12}$

Britain believed it further possible that Germany would venture to regain what she had lost by attempting to reverse the Treaty of Versailles. Both the Germans and the Turks had felt robbed by the treaties signed at Paris - Sèvres was to the Turk what Versailles was to the German. Not only had German engineers helped the Turks replace all the breech-locks demanded by the Great Powers at the Armistice; but Mustapha Kemal's plan of attack was identical to that employed by Marshall von Hindenburg and General Ludendorff in March 1918, and copied from manoeuvres by Von Moltke in $1870 .^{13}$

Britain was furthermore afraid that the Turkish victory over Greece would be viewed as a victory of Islam over Christendom. This would have serious repercussions in her Empire and, as it was, reports were already being received that the Turkish successes had caused ferment in India and that Turkish irregulars had penetrated Mesopotamia (Iraq). Britain feared a Jihad and prepared to face a most serious disturbance in the Islamic world which she thought might have repercussions in British Africa. Militant Islam held the potential to weaken European power and prestige the world over.

It was clear to the War Office, that if the situation developed, it could not be met by a passive defence only. Experience had taught that a vigorous offensive was the cheapest and most effective defence. The British troops available in the Middle East were a small fraction of the

\footnotetext{
Diverse Archives Group 1 (hereafter Diverse), Box 60, file 'War in Asia Minor', "Strategical appreciation of TurkoGreek War and possible military developments" compiled by the Chief of the General Staff, 19 Sep 1922.

10 Diverse, Box 60, file 'War in Asia Minor'. "Strategical appreciation of Turko-Greek War and possible military developments" compiled by the Chief of the General Staff, 19 Sep 1922.

11 Diverse, Box 60, file 'War in Asia Minor'. "Strategical appreciation of Turko-Greek War and possible military de velopments" compiled by the Chief of the General Staff, 19 Sep 1922.

12 Kemal and his masters; Does Moscow rule Angora?, Cape Times, 19 Sep 1922.

13 Well Led and Finely Equipped: General Townshend's View of the Turks, The Friend . 2 Sep 1922.
} 
force that would be required to cope with the serious situation that might have arisen in Asia Minor. It was estimated that a campaign in Mesopotamia and Persia (Iran) and the defence of India, would require twelve to twenty divisions within six months of the outbreak of war; and that in the case of a world war, Britain would have to mobilize no less than 52 divisions. ${ }^{14}$

The first British troops in occupation at Constantinople were the remnants of the Salonica force, strengthened later by the South Russia Mission, which had co-operated with the illstarred Denikin. This force had included several Indian units which were replaced with British troops by September 1922. There was no doubt in the British government that their troops would welcome a war with Turkey. The British army had a profound and detailed knowledge of the local population, and General Sir Charles Harrington, their man on the spot, was a soldier in the true sense of the word. A man to be relied on. However, the Turks, with the international support that they were receiving, were capable of overwhelming Chanak and planting guns along the western coast of Turkey to interfere with the shipping in the straits. ${ }^{15}$ The British garrisons had to be strengthened.

On 16 September 1922, Lloyd George announced that the Dominions, Rumania and $\mathrm{Yu}$ goslavia, had been asked to promise military support to help Britain, France and Italy defend the Dardanelles. ${ }^{16}$ (In fact, Britain had first raised the question of Dominion support to militarily assist Britain in the event of a world crisis, at the 1921 Imperial Conference.) Dominion support would immensely strengthen the position of the Allies.

\section{THE QUESTION OF SOUTH AFRICAN PARTICIPATION}

For the Union of South Africa, participation was a very delicate issue; and the opposition $\mathrm{Na}$ tional Party was violently opposed to the despatch of a South African contingent overseas. In a speech at Clanwilliam, Dr D.F. Malan (NP, MP Calvinia) stated that South Africa was again faced with the choice of participating in another war of destruction or keeping out of a difference in which she was not involved. Malan denied any agreement or obligation, legal or moral, to help Britain with her wars: ${ }^{17}$
"Die Dardanelle is nie ' $n$ druppel van ons bloed of ' $n$ sjieling van ons geld wêrd (sic) nie, en Suidafrika behoort hom neutraal te verklaar". Over the following month, the National Party made use of every opportunity to again lay down their traditional policy regarding the military participation of South Africa, outside the boundaries of the Union. On 22 September

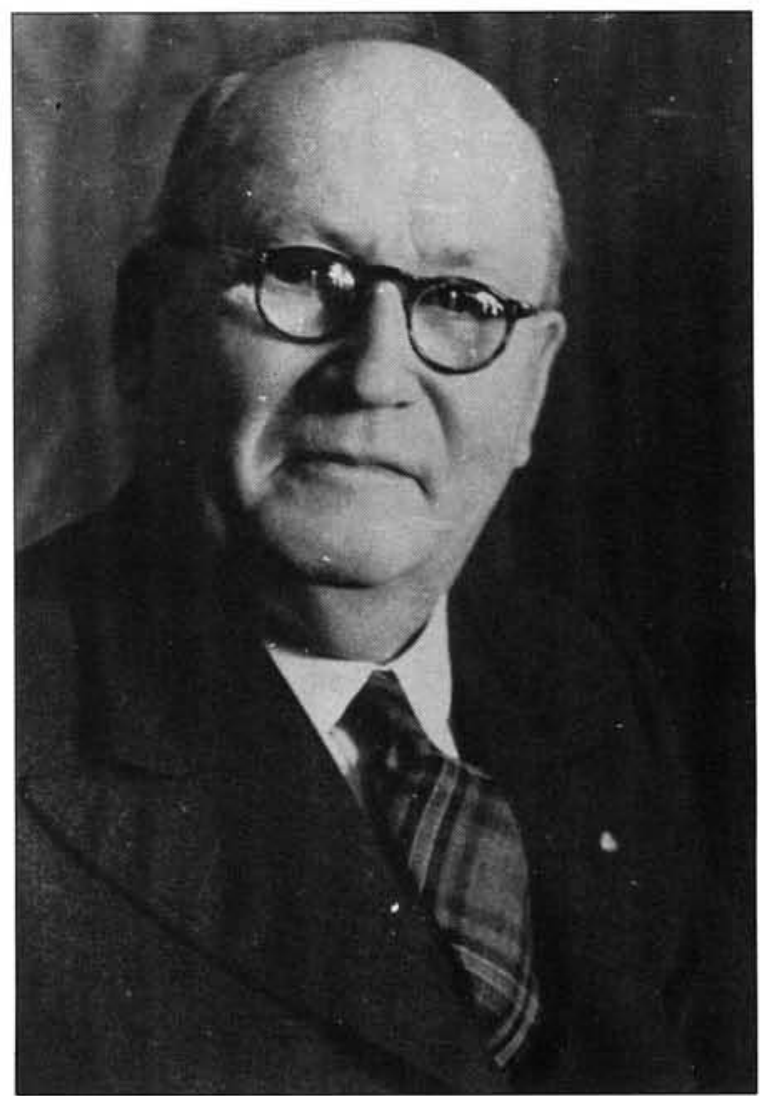

Dr D.F. Malan vehmently opposed the despatch of a South African contingent to Asia Minor.

1922, Tielman Roos (NP, MP Lichtenburg) was quoted in the press: ${ }^{18}$

"Ons is absoluut daarteen gekant om die Unie te stoot in die bynes van Europese en Asiatiese politiek en oorloë. Dus sal die Nasionale Party veg teen die versending van ' $n$ enkele Afrikaner-Engels- of Afrikaanssprekende - en die uitgawe van ' $n$ enkele pennie in verband daarmee. Ons medeburgers van Engels, van Hollands en van ander afstamming, is vir ons te veel wêrd (sic) om hulle daar te verloor. Ons het hulle nodig om Suid-Afrika op te voer".

Similar sentiments under comparable conditions in 1914, had resulted in a national rebellion which cost the country some $£ 5$ million; numerous lives; had held up the army for many months $;{ }^{19}$ and had embittered many Afrikaners against Botha and Smuts. Understandably, Jacobs. "Tussen twee wêreldoorloë" in R.J. Bouch (ed), Infantry in South Africa, 1652-1976 (Pretoria 1977), pp. 127-8. 
Smuts, now the South African premier, was unwilling to risk another rebellion, particularly so soon after the Rand Strike.

Furthermore, the Union Defence Forces had withered from a strength of 254666 during the First World War, to a meagre 39667 . This figure excluded the Class B Reserve and the 142399 members of the infantry-orientated Defence Rifle Associations, many of whom had a Nationalist orientation and would not have been prepared to serve outside the borders of the Union (table 1). ${ }^{20}$ ous experience, the minimum force which could be raised in response to any appeal for a contingent to serve overseas was 10000 with a strong Native Labour Corps. ${ }^{23}$

Nonetheless, while the General Staff was pondering the question of participation, numerous offers for service were received by the Defence Secretariat from the public. The cables from the first of these volunteers reached Defence Headquarters on 18 September $1922,{ }^{24}$ the day on which Lloyd George's appeal for support was published in South African newspapers. ${ }^{25}$

\begin{tabular}{|lrcr|}
\hline & OFFICERS & OTHER RANKS & TOTAL \\
Permanent Force & 168 & 1616 & 1784 \\
RNVR & 31 & 583 & 614 \\
CGF and ACF & 1450 & 6861 & 8311 \\
Reserve of Officers & 2207 & 26751 & 26751 \\
Class A Reserve & & 35811 & 39667 \\
TOTALS & $\mathbf{3 8 5 6}$ & $\mathbf{3 5 6 7}$ & \\
\hline
\end{tabular}

Table 1 : Strength of the Union Defence Force excluding the Class B Reserve, 1922.

It was impossible to say what portion of the British forces could be expected from South Africa. In the case of a world war, the War Office expected South Africa to contribute one division. For lesser emergencies, such as the developing crisis in Asia Minor, the initial input of a composite infantry brigade was considered by the War Office to be a fair contribution. ${ }^{21}$

Any such contingent would have had to be composed entirely of volunteers as neither the Permanent Force, a scanty 1784 (table 1), nor the Active Citizen Force as such,22 would have been available for service overseas. Taking as a guide the numbers who volunteered for service during the First World War, the General Staff estimated at the time of the 1921 Imperial Conference that the Union could furnish a force of 25000 men for service overseas. However, in the event of heavy casualties on the scale of the Western Front, they believed that the Union would not be able to keep such a contingent in the field for more than a year. Based on previ-
South Africa was once again divided on precisely the same issue which had cleaved the country in August 1914. Nationalists feared that the defence of the neutral zone would develop into a new world war, a part in which they were determined not to play. The Cape Times, on the other hand, stressed the duty of the Union government to give its full moral support to the Allies and, if needed, send a force and cooperate in defensive measures. New Zealand and Australia immediately responded to the call of Britain, and English South Africans hoped that the governments of South Africa and Canada would do the same and so strengthen the position of the Allied Powers. ${ }^{26}$

Soon, as a result of media reports and rumours that a South African contingent was being formed, numerous offers of service flooded into Defence Headquarters, from men and women who were willing to serve in a South African contingent, or as individuals should the Union government decide not to send a force. Some of these volunteers, nursing sisters, accountants and ex-infantry officers, had served during the last war in Egypt, the Balkans and even the Dardanelles. It is clear that many of them were extremely anxious to join. A number of volunteers reported to their local magistrates for immediate enlistment; while a certain Greenwood, whose telegram was the first to be received at the Defence Secretariat, even made use of a personal friend within the department

\footnotetext{
F.J. Jacobs: "Tussen twee wêreldoorloë" in R.J. Bouch (ed): Infantry in South Africa, 1652-1976 (Pretoria 1977), p.128.

21 Diverse, Box 60, file 'War in Asia Minor'. "Strategical appreciation of Turko-Greek War and possible military developments" compiled by the Chief of the General Staff, 19 Sep 1922.

22 The Active Citizen Force, as such, was not available. However, the General Staff did recognize that such a large percentage of a unit might volunteer as to warrant its acceptance as a unit of the contingent.

23. Archives of the Chief of the General Staff, Group 1 (hereafter CGS), Box 12, file 12 Union Force for Overseas, Appendix " $D$ " memorandum on Estimated Manpower available in the Union for military operations Overseas.

24 DC, Box 522, file 54626 War between Turkey and Greece-Offers of Service.

25 Defend The Straits; Britain's appeal to the Dominions, Rand Daily Mail. 18 Sep 1922.

26 The Kemalist Crisis, Cape Times, 19 Sep 1922.
} 
to influence a decision. ${ }^{27}$ However, in order to avert a spontaneous mobilization by 'British' South Africans, the Defence authorities made it known that, for the moment at least, a contingent would not be sent. The Deputy Assistant Adjutant General wrote to the Magistrate at Dordrecht on 25 September 1922 ?

"With reference to your telegram ... I beg to inform you that no recruits are at present required for service in connection with the war in the Near East".

This must have come as a surprise to many of the volunteers, who were apparently convinced that, with Smuts as prime minister, South Africa would be among the first to offer her services it was perhaps for this reason that R.C.S. Broadbent, a Nyasaland tobacco proprietor and a veteran of both the Zulu (1906) and the First World wars, offered to serve with a South African contingent. ${ }^{29}$ However, as soon as the news was out that South Africa would probably not send a contingent to Asia Minor, another man "very desirous to take part like a true British subject", approached the Department of Defence to assist him to reach the British army in the Dardanelles. ${ }^{30}$ This was, of course, something which the Defence authorities would not do although they apparently did not object to South Africans finding their own way to the theatre to enlist with the British forces. ${ }^{31}$

In the meantime, the Union Defence authorities began to prepare for a major war and on 19 September 1922, the decision was taken to purchase ten thousand new rifles. ${ }^{32}$ Two days later, the Minister of Defence, Colonel $\mathrm{H}$. Mentz, began to consider the formation of a composite brigade of 7617 men for a six month campaign. The brigade was to comprise. ${ }^{33}$

a Brigade Headquarters

4 infantry battalions field artillery (seven batteries each of six 18 pounders, and one battery of six 4.5 inch Howitzers)

2 signal sections

a field ambulance

a train company

a Reserve Depot Advance Base

a Reserve Training Depot South Africa

The estimated cost of maintaining this brigade overseas for a six month period totalled some $£$ $1135486 .{ }^{34}$

However, for South Africa, the whole question of military participation simply blew over. When Lloyd George issued his statement on 16 September 1922, General Smuts was away in Zululand, remote from the telegraph, the telephone and the wireless; and, in his absence, no immediate decision on participation was made. The Union government was thereby spared the necessity of replying to Britain's awkward telegram. ${ }^{35}$

As far as South Africa was concerned, very important questions of policy were involved. At the 1921 Imperial Conference, Smuts had stated that the deployment of South African troops in Imperial interests would first have to be put before a special sitting of Parliament. The Smuts government was, therefore, not prepared to dispatch troops in 1922 without calling Parliament together; and they were relieved when the more re-assuring situation on the ground in Asia Minor, rendered that step unnecessary. Parliament was not convened and no decision was taken to send South African troops to the Straits. The parliamentary debate would undoubtedly have slumped into the constitutional question of the relationship between Britain and the Dominions. If the Dominions had the higher status that was claimed, then

27 DC, Box 522, file 54626 War between Turkey and Greece - Offers of Service. Enc 1 telegram Greenwood - Lewis Defence Finance, $18 \mathrm{Sep}$ 1922, which reads: "Have telegraphed defence volunteering service shall be happy to lend a hand if developments warrant".

28 DC, Box 522, file 54626 War between Turkey and Greece - Offers of Service. DAAG - Magistrate Dordrecht, 25 Sep 1922.

29 DC. Box 522, file 54626 War between Turkey and Greece - Offers of Service. R.C.S.Broadbent - Staff Officer for Defence, Pretoria, 1 Oct 1922.

30 DC, Box 522, file 54626 War between Turkey and Greece - Offers of Service. S.J.Bane - Minister of Defence, 2 Oct 1922.

31 DC. Box 522, file 54626 War between Turkey and Greece - Offers of Service. Deputy Assistant Adjudant General S.J.Bane, 12 Oct 1922.

32 CGS, Box 12, file 21 Purchase of Rifles. Chief of the General Staff - Quartermaster General, 19 Sep 1922.

${ }_{33}$ DC, Box 522, file 1/54626 Overseas Expeditionary Forces - Turkish-Greek War 1922. Chief of the General Staff -

Quartermaster General and Financial Under Secretary, 21 Sep 1922.

34 CGS, Box 12, file 22 Union Force for Overseas - Cost of a Composite Brigade. This figure was calculated as follows:

Pay and Allowance

Rations

Personal Equipment and Small Arms

Guns, Ammunition and Transport

Forage and Farriery

TOTAL
£ 637855

141560

210902

115957

29212

1135486

35 A Lucky Delay, The Daily Despatch, 26 Sep 1922. 
clearly they had the right to consider such an invitation as issued by Lloyd George, on its merits. $^{36}$

By the time Smuts had returned to Pretoria some ten days later, the situation had undergone so marked a change that the task of replying to Lloyd George's message had become a comparatively simple matter. Not only did the situation on the ground in Asia Minor improve and the friction between the Allies diminish, but an overdue explanation had been given by the Imperial government of its action in sending out a call to the Dominions. The situation had improved to such an extent, that the dispatch of troops to the theatre from the Dominions, was viewed as "probably not necessary". ${ }^{37}$

On 26 September 1922, Smuts simply sent a message to the British prime minister, stating that although South Africa understood and appreciated Britain's desire to maintain the freedom of the straits of the Dardanelles and the Bosphorus, the Union would not participate in a war in Asia Minor. The internationalization of the Straits had been an important outcome of the First World War, and, according to Smuts, they "should be placed under the League of Nations". 38

The South African premier, personally, would have undoubtedly been keen to assist Britain by sending a contingent. However, after the 1914 Rebellion, both he and Louis Botha were branded as enemies of Afrikanerdom. Smuts knew that he was hated by nationalist Afrikaners and did not want to provide the vehicle whereby they could give vent to their anger. $\mathrm{He}$ certainly did not want to risk another revolt.

Had Smuts been forced to reply a week earlier, he could hardly have avoided giving offence to many people. Had he followed the line of Australia and New Zealand and undertaken enthusiastically to send a contingent, he would have aroused the anger of the National Party and the Labour Party, and incurred the displeasure of many of his own supporters. On the other hand, had Smuts declined to help in any way, he would have offended the feelings of many South Africans loyal to Imperial interests; and would have compared very badly with the premiers of Australia and New Zealand ("When the Empire calls, there can only be one answer"). The delay resulting from his absence in Zululand had freed him from this dilemma. (In-

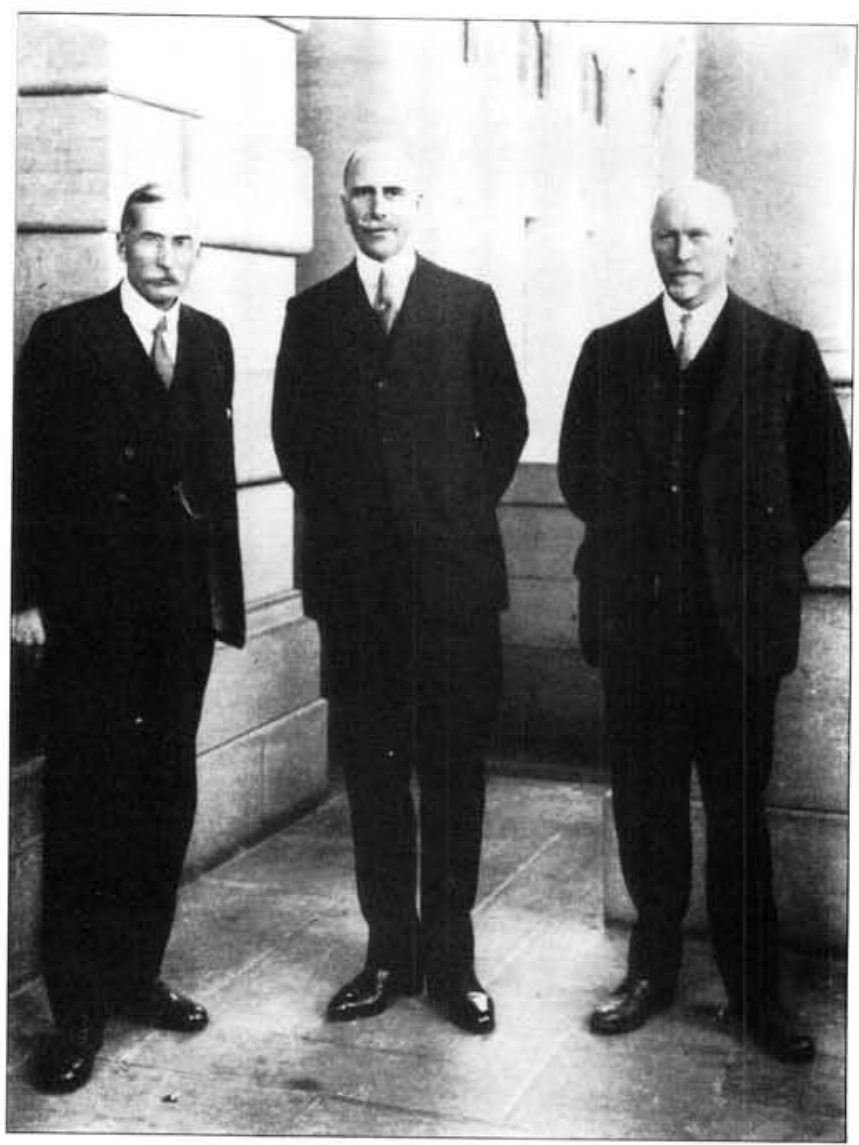

Generals Hertzog and Smuts with the governor general of the Union, the Earl of Athlone (centre), in 1924.

terestingly, 28 years later, another South African prime minister found himself in the same place and more or less in the same position, when the Korean war broke out in 1950.)

\section{THE CRISIS AT CHANAK}

Lloyd George's announcement of 16 September had incited the Turks to action, both by its threatening tone and because it contained no reference to the territorial demands of the Turkish nationalists in Eastern Thrace. In consequence, the Turkish army advanced towards the neutral zone. France and Italy withdrew their troops, leaving the British troops alone in the defences.

A force of approximately 2000 Turkish Cavalry with light artillery, occupied Erenki near Chanak, well within the neutral zone (map 3). The War Office believed that the Turks would attempt to overwhelm the British troops by sheer force before re-inforcements could arrive. ${ }^{39}$ General Harrington immediately informed Kemal of the breech in the armistice

\footnotetext{
South Africa and the Balkans, The Friend, 27 Sep 1922.

A Lucky Delay, The Daily Dispatch, 26 Sep 1922.

South Africa and the Balkans. The Friend, 27 Sep 1922 (quoting Smuts).

Diverse, Box 60, file 'War in Asia Minor'. Captain G.III - Chief of the General Staff, undated.
} 
conditions, and gave him a time limit to withdraw.

On 23 September 1922, the British and French foreign ministers, Lord Curzon and M.Poincaré, managed to broker a truce. In the meantime, the Turkish cavalry had advanced almost up to the British wire at Chanak, and only the tact and firmness of General Harrington as well as his sincere desire to prevent war, averted a disaster and so for the moment the danger of a new world war which could easily have plunged the whole of Europe into chaos, was averted. This incident clearly demonstrated the value of an armed force as a vehicle for peace.

\section{TREATY OF LAUSANNE (1923)}

British, French and Turkish representatives met at Mudania on 3 October and, after difficulty, an armistice was signed on 11 October 1922. The Turks agreed to respect the neutral zone; and the Greeks were forced to evacuate Eastern Thrace : although the Turks were not to take occupation, pending a final settlement of peace..$^{40}$

The final settlement reached at Lausanne was equally difficult, the situation remaining uncertain well into the next year. The Greek cabinet, again under the leadership of Venizelos, was divided; and, during their prime minister's absence in Switzerland, the rest of the cabinet in Athens had to be dissuaded by the British from issuing an ultimatum to Turkey. ${ }^{41}$ Greek opinion was inflamed against Turkey owing to bad treatment of Greek prisoners of war, highhanded action regarding banks in Smyrna and

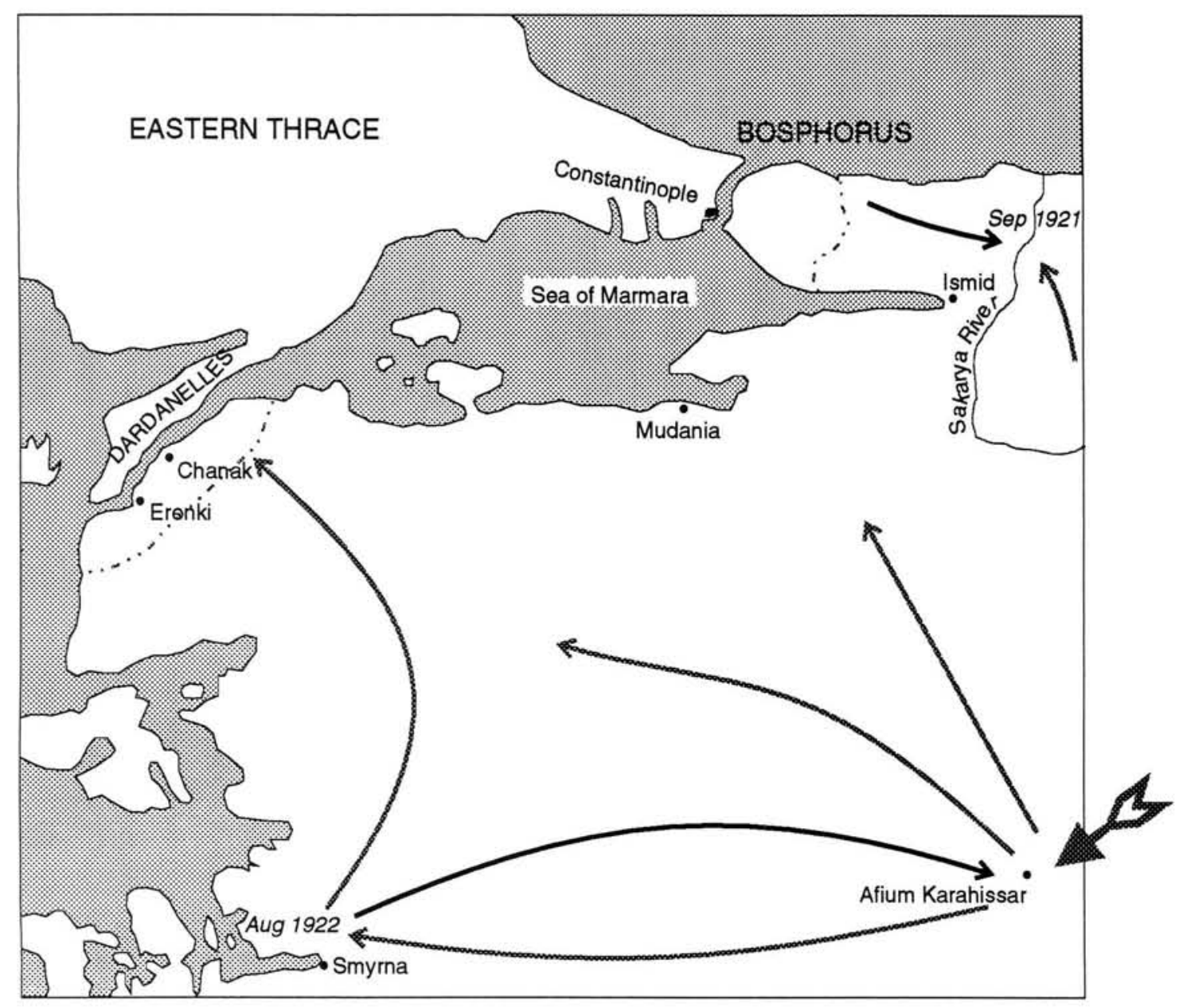

Line on which the Turks halted after the Mudania Conference 1922.

$\rightarrow$ Advance of Greek army.

$\rightarrow$ Turkish counter-offensive.

Map 3: The Chanak crisis. 
Constantinople and the expulsion of Greeks from Asia Minor. ${ }^{42}$

Turkey pressed for reparations and Greece remained determined not to pay. This naturally presented a difficult position. ${ }^{43}$ At any stage, the war might have flared up again. Sir Horace Rumbold, the British High Commissioner in Constantinople, managed to convince the Greek commander-in-chief to take no action without the authority of the Greek government; who, in turn, had to be persuaded to do nothing which would provoke the resignation of Venizelos. The Greek government eventually showed themselves willing to compromise, but stated clearly, that if the Turks were intractable or evasive, war would be their only alternative.

The Turks, however, were unwilling to accept moral satisfaction only. They wanted some form of reparation; and, if Greece had no money to pay, Turkey would satisfy herself with the appropriation of the Greek navy. Both sides seemed averse to arbitration. ${ }^{44}$

The indignant Greek cabinet was still divided as to war. Information in Athens suggested that in the event of war, Yugoslavia would threaten the Bulgarian frontier and hinder Sofia from helping Turkey. France and Italy joined Britain in warning the Greeks against precipitating hostilities. Toward the end of May 1923, the Greek government began organizing bands of irregulars on the islands for guerilla warfare on mainland Turkey. Turkish aeroplanes threatened reprisals and two Greek torpedo boats were sent to the coast of Asia Minor to protect the raiders. At the same time, in contravention of the convention signed at Mudania, 7000 Turkish troops were reported to have crossed from Asia Minor into Eastern Thrace. ${ }^{45}$

Just as war began to seem inevitable, the representatives at Lausanne reached agreement and a treaty was signed on 24 July 1923. Turkey regained Adrianople from Bulgaria, and Eastern Thrace from Greece. All the Greeks still living in Turkey and all the Turks living in Greece were sent 'home'. Nearly $1^{\circ}$ million people were uprooted and moved from places where their ancestors had settled many generations previously. The re-settlement of these Greeks in Western Thrace displaced expatriate Bulgarians and triggered a Greek-Bulgarian war, which was stopped almost before it stared by the League of Nations. ${ }^{46}$

Although the neutralized zone around the Straits was maintained, it was vastly reduced in size; and Turkey refused to submit to any limitations on her armaments or the size of her army, so becoming the only ex-enemy country not to be restricted on the strength of her forces. The Treaty was humiliating to the Great Powers. Turkey had defied them. She refused to submit to the terms of the Treaty of Sèvres; and forced the Allied Powers to sign a fresh treaty with her at Lausanne - a neutral venue. ${ }^{47}$

\section{CONCLUSION}

The 1921 Imperial Conference had spoken optimistically of "a united understanding and common action in foreign policy" for the British Empire. ${ }^{48}$ The world was notified that the Empire followed a combined foreign policy. However, when the Empire was suddenly forced by an unexpected international crisis, to make a combined executive decision, the moment of truth weighed the formula of the 1921 Conference and was found to be wanting. A year after the conference, a series of events proved beyond all doubt that it was simply not possible to formulate one common policy for an entity subject to so many uncertainties, stresses and variables. ${ }^{49}$

41 Central Archives Depot, State Archives, Pretoria (hereafter CAD), archives of the Prime Minister of the Union (hereafter PM), PM 50/3/B The Greek attitude towards the Turks. Telegrams Secretary of State for the Colonies Governor General, Cape Town, 9 and 10 May 1923.

42 CAD: PM, 50/3/B The Greek attitude towards the Turks. Telegram Secretary of State for the Colonies - Governor General, Cape Town, 10 May 1923

43 CAD: PM, 50/3/B The Greek attitude towards the Turks. Telegram Secretary of State for the Colonies - Governor General, Cape Town, 15 May 1923

a4 CAD: PM, 50/3/B The Greek attitude towards the Turks. Telegram Secretary of State for the Colonies - Governor General, Cape Town, 19 May 1923.

45 CAD: PM, 50/3/B The Greek attitude towards the Turks. Telegram Secretary of State for the Colonies - Governor General, Cape Town, 25 May 1923

46 G.M.Gathorne-Hardy : A short history of International Affairs, 1920-1939 (London, New York and Toronto, 1950) pp.94-95.

47 A.J.Grant and H.Temperley : Europe in the Nineteenth and Twentieth Centuries, 1789-1950 (London 1980), pp.448 449; Sir Charles Petrie: Twenty Years' Armistice - and After; British Foreign Policy since 1918 (London 1940), pp.5355: and A. Clayton: The British Empire as a Superpower, 1919-1939 (Basingstoke 1986), p.241.

48 I. Jennings: The British Commonwealth of Nations (London 1956), p. 133 as quoted by D.O. Rhoodie: Suid-Afrika: van koloniale onderhorigheid tot soewereine onafhanklikheid (Johannesburg 1974), p.110.

49 D.O. Rhoodie: Suid-Afrika: van koloniale onderhorigheid tot soewereine onafhanklikheid, p. 110 
Britain had committed herself to provide support for Greece in her war against Turkey, and so ensure the neutrality of the Straits. However, as a result of the demobilization and rationalization which had taken place in the Union Defence Force in 1919 and 1920, South Africa found herself to be without the military infrastructure to act in concert with the Imperial authorities. Furthermore, the changed constitutional structure of the British Empire had divided the dominions on the question of participation : Australia and New Zealand eagerly offered their assistance; Canada refused to take part; and the British came to realise that military support from South Africa would not be automatic - even with General Smuts at home in Groote Schuur.

The war in Asia Minor cast a bright light upon a very important question which continued to come to the fore of the political stage in all of the Dominions, even after the crisis had dissipated: Were the Dominions bound by the Imperial conferences to participate in all of Britain's wars? 